\title{
CD40LG wt Allele
}

National Cancer Institute

\section{Source}

National Cancer Institute. CD40LG wt Allele. NCI Thesaurus. Code C50970.

Human CD40LG wild-type allele is located within Xq26 and is approximately $12 \mathrm{~kb}$ in length. This allele, which encodes CD40 ligand protein, plays a role in B-cell regulation, proliferation and adhesion. 